\title{
A INFLUÊNCIA DA TECNOLOGIA NO DESENVOLVIMENTO DA CRIANÇA PRÉ-ESCOLAR E ESCOLAR
}

\author{
Thaís Aluane Silva Santos ${ }^{1}$, Kátia Terezinha Alves Rezende ${ }^{2}$, lone Ferreira Santos ${ }^{2}$ e \\ Silvia Franco da Rocha Tonhom ${ }^{2}$ \\ 1,2Faculdadede Medicina de Marília (Famema), São Paulo, Brasil. thais_aluane@hotmail.com \\ ²katia@famema.br; ionefs13@gmail.com; siltonhom@gmail.com
}

\begin{abstract}
Resumo: $\mathrm{O}$ objetivo geral dessa investigação é o de analisar o uso das tecnologias e seu impacto no desenvolvimento da criança e os específicos, identificar quais são os meios utilizados pelas crianças; identificar a intensidade do uso das tecnologias mais comuns; analisar como os responsáveis acompanham o uso; identificar os benefícios e os malefícios que as tecnologias trazem para a vida das crianças. O estudo foi realizado nas Unidades Básicas de Saúde de um município do interior paulista, onde entrevista-se o responsável que acompanhava a criança. Optase pela análise de conteúdo, modalidade temática. $O$ estudo explicitou que a televisão e o celular são as tecnologias mais acessadas. A análise dos dados nos permitiu identificar quatro temas: A) O conteúdo assistido no acesso a tecnologia; B) O uso da tecnologia altera comportamento; C) O monitoramento no uso das tecnologias e D) O desenvolvimento da criança e o uso da tecnologia.
\end{abstract}

Palavras-chave: Crianças; Tecnologias; Telefone Celular; Televisão; Desenvolvimento Infantil.

\section{THE INFLUENCE OF TECHNOLOGY ON PRESCHOOL AND SCHOOL CHILD DEVELOPMENT}

Abstract: The general objective of this investigation is to analyze the use of technologies and their impact on the child's development and the specific ones, to identify which are the means used by children; identify the intensity of use of the most common technologies; analyze how those responsible person are monitoring the use; identify the benefits and harms that technologies bring to children's lives. The study was carried out in the Basic Health Units of a city in the interior of the state of São Paulo, where the responsible person for accompanying the child is interviewed. We opted for content analysis, thematic modality. The study made explicit that television and cell phones are the most accessed technologies. Data analysis allowed us to identify four themes: A) The watched content in accessing technology; B) The use of technology changes behavior; C) Monitoring the use of technologies and D) Child development and use of technology.

Keywords: Child; Technology; Television; Cell Phone; Child Development.

\section{INTRODUÇÃO}

Atualmente as tecnologias (televisão, celular, computadores, tablets, vídeo games etc.) são fundamentais em nossas vidas, em casa, nas escolas, praças e restaurantes. Está cada vez mais comum encontrar pessoas conectadas ao invés de sair, jogar conversa fora. Vemos famílias inteiras com objetos tecnológicos e com o mínimo possível de contato físico social (Pereira \& Arrais, 2015).

Segundo Wallbach (2010), a internet não tem censura, não tem limites. As crianças estão dispostas e podem ver cenas de sexo e todas as perversidades inimagináveis apertando apenas um botão e do seu próprio quarto. O mundo virtual proporciona contatos, relacionamentos com diversas pessoas, porém, nesses relacionamentos não há frustração. 
Contudo, na vida real, possuem dificuldades de se relacionar com as pessoas que estão a sua volta. Além disso, a criança encontra em um click tudo que a humanidade levou milhares de anos para descobrir.

A tecnologia influencia comportamentos por meio do mundo digital, modificando hábitos que podem causar prejuízos e danos à saúde, como dificuldades de socialização e conexão com outras pessoas e dificuldades escolares; problemas mentais, aumento da ansiedade, violência, cyberbullying, transtornos de sono e alimentação, sedentarismo, problemas auditivos, visuais, posturais e lesões de esforço repetitivo (LER); problemas envolvendo a sexualidade; acesso facilitado a pornografia, pedofilia e exploração sexual; compra e uso de drogas; pensamentos ou gestos de auto agressão e suicídio; além das "brincadeiras" ou "desafios" online que podem ocasionar consequências graves e até o coma por anóxia cerebral ou morte (Azevedo, 2016).

É reconhecida a importância dos avanços da tecnologia atualmente, entretanto, compreende-se que esta pode tornar-se um sério problema prejudicando o desenvolvimento da criança quando utilizada de forma inadequada. Constata-se que existem poucos estudos a respeito dessa problemática.

Observa-se no cotidiano dos serviços de saúde e da vida que as crianças utilizam de tecnologias de forma abusiva sem o acompanhamento dos pais e responsáveis. Esses oferecem as diferentes mídias com intuito de acalmá-las e de entretê-las para que possam realizar suas atividades. Desta forma, questiona-se: Como as crianças utilizam as tecnologias? Quais são elas? Os responsáveis acompanham esse uso? De que forma? Qual o impacto (benefícios e malefícios) desse uso na vida da criança?

Os objetivos desse trabalho é analisar o uso das tecnologias e seu impacto no desenvolvimento da criança; identificar quais as tecnologias mais comuns utilizadas pelas crianças; identificar a intensidade do isso das tecnologias mais comuns; analisar como os responsáveis acompanham o uso das tecnologias mais comuns e analisar os benefícios e os malefícios que as tecnologias mais comuns trazem para a vida das crianças.

\section{METODOLOGIA}

Para alcançar os objetivos dessa investigação decidiu-se pela pesquisa de abordagem qualitativa. Para Minayo (2016) a pesquisa qualitativa trabalha com o universo dos 
significados, dos motivos, das aspirações, das crenças, dos valores e das atitudes, portanto, um sentido mais subjetivo e impressionista; produzindo uma compreensão e interpretação sobre o tema.

De acordo com a resolução 466/2012 do Conselho Nacional de Saúde que regula a pesquisa envolvendo seres humanos, o projeto foi submetido ao Comitê de Ética em Pesquisa Envolvendo Seres Humanos da Faculdade de Medicina de Marília, sendo aprovado no dia 04-02-2019, parecer de número 3.130.691.

Os participantes que concordaram em participar da pesquisa assinaram o Termo de Consentimento Livre e Esclarecido (TCLE).

O estudo foi realizado nas Unidades Básicas de Saúde (UBS) de um município do interior paulista. Nesse existem 12 UBS distribuídas nas quatros regiões de saúde, norte, sul, leste e oeste. Foi escolhida aleatoriamente uma UBS por região, em que sua área de abrangência possuía um número maior de crianças na faixa etária de dois a deis anos.

Utiliza-se a entrevista semiestruturada, realizada com os responsáveis que acompanhavam as crianças no atendimento realizado nos serviços de saúde, como consulta de pediatria e vacinação. Segundo Minayo (2016), a entrevista semiestruturada se dá por perguntas abertas ou fechadas feitas pelo entrevistador sem se prender ao roteiro previamente estruturado. Sendo assim, o roteiro é apenas um norteador na hora da entrevista.

Dessa forma, emprega-se um instrumento, o qual continha dados de identificação como, nome, idade, sexo, escolaridade, estado civil, ocupação, grau de parentesco, religião do entrevistado e idade, sexo e escolaridade da criança; e questões norteadoras, como, A criança faz uso de tecnologias? Quais são elas? Qual a frequência desse uso? A frequência altera nos finais de semana e nas férias? Como? Você ou alguém da família define período em que as tecnologias serão utilizadas? Se não, porque? Se sim, como? Quais as reações da criança diante dessa definição? Você e ou alguém da família acompanha esse uso? Como?Você acha que o uso dessas tecnologias pode trazer benefícios para o desenvolvimento da criança? Quais são eles?Você acha que o uso dessas tecnologias pode trazer malefícios para o desenvolvimento da criança? Quais são eles?O uso da tecnologia compromete o estudo e o desempenho escolar?Você acha necessário/importante o acompanhamento do uso da tecnologia?Você deseja falar algo mais sobre esse tema? 
Inicialmente foram contatados os responsáveis das crianças, na sala de espera, para vacinação ou consulta de pediatria sobre a pesquisa e o interesse em participar.

As entrevistas foram realizadas por uma das pesquisadoras, atingindo uma saturação com 20 entrevistas, sendo que cinco responsáveis tinham duas crianças, totalizando 25 entrevistas. Compreende-se por saturação a repetição, redundância das ideias manifestas pelos pesquisados, não havendo, portanto, necessidade a inclusão de novos participantes (Minayo, 2014).

As entrevistas tiveram uma duração média de 7 minutos e 85 segundos, foram transcritas fidedignamente, e para garantir o sigilo e a identidade dos pais e/ou responsáveis, eles são identificados pela letra $\mathrm{E}$, que se refere a entrevistado e numerados de 1 a 25 .

A análise foi realizada a partir da análise de conteúdo na modalidade temática que tem como propósito identificar os núcleos de sentidos da comunicação e que representem algo para o alcance dos objetivos (Minayo, 2016).

Nesse sentido, busca-se a compreensão dos significados no contexto da fala, nega-se e critica-se a análise de frequências das falas e palavras como critério de objetividade e cientificidade e ultrapassa-se o alcance meramente descritivo da mensagem, para atingir, mediante interferência, uma interpretação.

Para tanto, inicialmente foi realizada a leitura exaustiva do material deixando-se impregnar pelo conteúdo, conseguindo-se ter uma visão do conjunto, apreender as particularidades, elaborar pressupostos, escolher a forma de classificação inicial e por fim definir os conceitos teóricos que orientaram a análise. Em seguida, realizou-se a exploração do material distribuindo-se os trechos das entrevistas em uma classificação que contemplou analisar o uso das tecnologias e seu impacto no desenvolvimento da criança. A partir de então, realizou-se uma leitura do conteúdo de cada classe fazendo um diálogo entre as partes do texto de análise. Após identificou-se, por meio de inferência, os núcleos de sentido que reorganizados constituíram quatro temas: o conteúdo assistido no acesso a tecnologia; o uso da tecnologia altera comportamento; o monitoramento no uso da tecnologia; e o desenvolvimento da criança e o uso da tecnologia, conforme apresentado no Quadro 1. 
Quadro 1 - Núcleos de sentido articulados aos temas

\begin{tabular}{|c|c|}
\hline Núcleos de Sentido & Temas \\
\hline $\begin{array}{l}\text { - Conteúdo assistido de acordo com a } \\
\text { idade }\end{array}$ & \multirow[t]{2}{*}{$\begin{array}{c}\text { Tema1 } \\
\text { O conteúdo assistido no acesso a tecnologia }\end{array}$} \\
\hline $\begin{array}{l}\text { - Conteúdo assistido inapropriado para a } \\
\text { idade }\end{array}$ & \\
\hline $\begin{array}{l}\text { - O uso da tecnologia desencadeia } \\
\text { comportamentos assertivos }\end{array}$ & \multirow[t]{2}{*}{$\begin{array}{c}\text { Tema } 2 \\
\text { O uso da tecnologia altera comportamento }\end{array}$} \\
\hline $\begin{array}{l}\text { - O uso da tecnologia desencadeia } \\
\text { comportamentos não assertivos }\end{array}$ & \\
\hline - Os pais monitoram o uso de tecnologias & \multirow{2}{*}{$\begin{array}{c}\text { Tema } 3 \\
\text { O monitoramento no uso das tecnologias }\end{array}$} \\
\hline $\begin{array}{l}\text { - Os responsáveis não monitoraram o uso } \\
\text { das tecnologias. }\end{array}$ & \\
\hline $\begin{array}{l}\text { - Potencializando o desenvolvimento da } \\
\text { criança devido ao uso da tecnologia }\end{array}$ & \multirow{2}{*}{$\begin{array}{c}\text { Tema } 4 \\
\text { O desenvolvimento da criança e o uso da } \\
\text { tecnologia }\end{array}$} \\
\hline $\begin{array}{ll}\text { - } & \text { Prejudicando o desenvolvimento da } \\
\text { criança devido ao uso da tecnologia } & \end{array}$ & \\
\hline
\end{tabular}

\section{RESULTADOS E DISCUSSÃO}

As tecnologias que as crianças mais acessam são a televisão e o celular, em média, quatro horas por dia. Raramente os entrevistados citaram o uso de tablet e computador, pois esses possuem a mesma finalidade do celular e vídeo game. Como a maioria das crianças estuda durante a semana, tanto em um período (manhã ou tarde) ou integral, elas utilizam mais aos finais de semana e nas férias. Algumas crianças não utilizam nos finais de semana e férias, pois os pais e outros membros da família estão no domicilio e acabam realizando atividades ao ar livre ou dormindo na casa de um amigo ou de parentes; essas utilizam menos as tecnologias.

Santos (2017) traz que a Academia Americana de Pediatria e a Sociedade Canadense de Pediatria recomendaram limites para a exposição das crianças a todo tipo de mídia (televisão, games, internet, smartphones etc.). Para as entidades, o ideal é que apenas depois dos dois anos de idade as crianças comecem a ter contato com esses aparelhos e por tempo limitado. Até os cinco anos, as crianças só deveriam ficar no máximo 1 hora diante das telas. O tempo aumenta para 2 horas para crianças de 6 a 12 anos e para 3 horas a partir dos 13 anos.

Os objetos tecnológicos consomem tempo considerável da rotina de muitas crianças na contemporaneidade. 
No entanto, a especificidade do tempo de consumo varia conforme a cultura e as condições de viver a infância, sobretudo em relação ao acesso e pertencimento à cultura digital (Fantin, 2015).

As crianças nascidas nessa cultura tecnológica são chamadas "nativos digitais", aprendem muito cedo a serem dependentes da tecnologia. Atualmente há a necessidade do domínio das ferramentas tecnológicas, que são cobradas pela escola, mercado de trabalho, na sociedade em geral. Com isso, as crianças são inseridas nesse contexto o quanto antes possível. Elas se sentem atraídas pelos objetos, domina-os naturalmente e dedicam boa parte do seu tempo (Pereira \& Arrais, 2015).

A seguir será realizada a apresentação e discussão dos temas identificados.

\subsection{O conteúdo assistido no acesso a tecnologia}

\subsubsection{Conteúdo assistido de acordo com a idade}

Os entrevistados especificaram o conteúdo assistido pelas crianças ao acessarem a televisão e o celular. Os desenhos vistos na televisão são de acordo com a faixa etária das crianças e geralmente, possuem classificação livre, como Peppa Pig, Marsha e o Urso, Patrulha Canina, entre outros. Como também os filmes Moana e O Rei Leão, com classificação livre e Frozen: uma aventura congelante a partir dos 3 anos; e novelas como As Aventuras de Poliana e Cúmplice de um Resgate, classificação livre.

"[...] é mais na idade dele mesmo. É desenhinho, é Rei Leão, Patrulha canina, Marsha e o Urso, é mais coisinha da idade mesmo dele, de 4 anos." (E16).

Em relação ao uso do celular, as crianças procuram se entreter com vídeos no YouTube, esses são educativos, interativos e de músicas infantis; ensinando as crianças sobre o alfabeto, os números e as cores, elas aprender a cantar e, consequentemente, enriquecem o vocabulário.

"Celular ela gosta, se deixa ela quer ouvir musiquinha, ver aqueles vídeo interativo, é que tem bastante vídeo para criança" (E18).

Algumas crianças, entre 7 a 10 anos, utilizam o YouTube para acompanhar canais de youtuber/blogueiros, como Luccas Neto (entretenimento e educação lúdica- teatro), Julia Mine Girl, Authentic Game e 2 Marmotas (game play, jogos diversificados/conteúdos), o conteúdo desses está voltado para crianças dessa faixa etária. 
"Ela costuma assistir desenho animado, canais [do YouTube]. Canais interativos, mas é só voltar nesses desenhos e esses canais." (E19).

Também vêem vídeos sobre trollagem, no qual os entrevistados se preocupam bastante, já que as crianças acabam reproduzindo o que esses vídeos mostram.

"É demais aquilo, aquele negócio de trollagem, ele assisti bastante." (E11). Como também vídeos sobre aula de balé, para aperfeiçoar a dança. "No celular ela gosta muito de ver [vídeo] as aulas de balé, que ela faz balé [...]" (E24).

O celular também é acessado para realizar pesquisa de escola (crianças na faixa etária de 9 a 10 anos), tirar foto (faixa etária de 2 a 4 anos), mandar áudio para parentes por meio do WhatsApp e jogos como da Barbie, Roblox (jogo online/mundo aberto, multiplataforma, multiverso), Minecraft (estratégia e construção) e FireFree (ação-aventura/jogo de batalha real).

“Tem mania naquele jogo FireFree, que tem lá [...]" (E11).

Constata-se que as crianças inseridas no mundo das mídias digitais, vivem criativamente a promoção da cultura em rede, fundem e confundem sentidos diversos do brincar. Imaginam e criam possibilidades de experimentar cada vez mais sensações (Canaan, Ribeiro \& Paolla, 2017).

Ao questionar as crianças sobre possíveis aprendizagens durante o jogo, elas costumam responder que "depende do jogo", ou que é possível "aprender inglês", "conhecer lugares", "aprender história/geografia" e outros (Fantin, 2015).

\subsubsection{Conteúdo assistido inapropriado para idade}

Alguns entrevistados também relataram que as crianças costumam assistir filmes de dança e de corrida, estes com classificação a partir de 12 anos; de ação para maiores de 14 anos e de terror para maiores de 16 ou 18 anos. E também programas de televisão, como Programa da Eliana para maiores de 10 anos; humorístico, a partir dos 16 anos e série como CSI, para maiores de 14 anos.

"[...] filme de ação, ele gosta bastante. Mais de corrida, filme de dança ele também gosta bastante, filme de terror [...]" (E15).

A minoria utiliza do vídeo game e o faz esporadicamente e na presença de um amigo com intuito de entreterimento. Os jogos que mais utilizam são os de futebol e Minecraft com 
classificação livre, luta (Mortal Kombat) e GTA (ação-ventura e tiro em terceira pessoa) para maiores de 18 anos e FortNite (jogo eletrônico de batalha real, mundo aberto, estratégia) para maiores de 13 anos.

"Vídeo game é quando tem um amiguinho em casa pra ele jogar futebol, que é o que ele treina” (E2).

É necessário desencorajar, evitar e até proibir a exposição passiva em frente às telas digitais, com exposição aos conteúdos inapropriados de filmes e vídeos, para crianças com menos de dois anos, principalmente, durante as horas das refeições ou 1-2 $\mathrm{h}$ antes de dormir (Azevedo, 2016).

$\mathrm{E}$ as crianças menores de seis anos precisam ser mais protegidas da violência virtual, pois não conseguem separar a fantasia da realidade. Jogos online com cenas de tiroteios com mortes ou desastres que ganhem pontos de recompensa como tema principal, não são apropriados em qualquer idade, pois banalizam a violência como sendo aceita para a resolução de conflitos, sem expor a dor ou sofrimento causado às vítimas, contribuem para o aumento da cultura de ódio e intolerância e devem ser proibidos (Azevedo, 2016).

Outra reflexão importante a ser feita diz respeito da criminalidade digital, a internet pode ser um campo de atuação de criminosos que agem no anonimato, não assumindo as responsabilidades pelos seus atos, aumentando de forma grave essa forma de crime (Souza \& Oliveira, 2016).

Embora pareça difícil encontrar um ponto de equilíbrio no uso da tecnologia, os pais devem estabelecer regras e trabalhar para que as crianças não exagerem na hora de usar os aparelhos eletrônicos. Desta forma, é importante os pais/responsáveis se auto examinar em relação ao uso das tecnologias, pois eles são os primeiros exemplos para os pequenos. Outro ponto é não estimular antes do tempo as crianças a manipulares os equipamentos. $O$ melhor é deixar que elas mesmas demonstrem interesse e só depois disso os pais podem mostrar a elas como usar os aparelhos de forma correta (Santos, 2017).

\subsection{0 uso da tecnologia altera comportamento}

\subsubsection{O uso da tecnologia desencadeia comportamentos assertivos}

O uso das tecnologias e o acesso a internet tem mudado o comportamento de crianças e adolescentes, transformando seus hábitos e modos de vida, hoje não é mais necessário se reunirem para diversão, pois através da internet, criam-se outras possibilidades como jogos 
on-line, bate-papos, chats, entre outros, formando-se novas redes sociais, mesmo estando isolados cada um em seu mundo virtual (Souza \& Oliveira, 2016).

Quando questionados sobre as reações que as crianças têm ao utilizar essas tecnologias, alguns entrevistados referiram que as crianças ficam felizes e vibram quando podem assistir televisão ou acessar o celular, se tornam espertas e criativas, aprendendo a contar número, a distinguir cores e a cantar as músicas.

"Muita vibração" (E2); e "Ah, um pouco animada sim, porque ela gosta bastando." (E14).

Alguns entrevistados falam que as crianças, ao verem os vídeos, questionam os responsáveis sobre tais atitudes vistas e passam a serem mais obedientes.

"Tem uns vídeos de umas meninas na internet que desobedece a mãe, aí briga, chora, aí ela começa a falar pra mim o que aconteceu, aí eu explico pra ela e falo: 'está vendo'; daí a mãe cansa da filha, vai embora e deixa a filha sozinha e a filha fica procurando a mãe... aí que explico pra ela, por isso que não pode desobedecer a mãe, porque acontece isso, a mamãe vai embora. O que acontece eu falo. E às vezes: 'está bom, eu vou obedecer'. Às vezes funciona.” (E13).

Eles falam que o celular foi uma maneira que encontraram para deixar a criança mais calma, já que ela era muito chorosa e manhosa, e eles têm a consciência de que isso não é bom, mas não viram outra maneira.

"O celular é uma maneira que a gente achou dela ver os vídeos dela, de dar um sossego, de dar uma acalmada nela e um pouco. [...], mas não é bom, a gente sabe o que não é bom." (E13).

Canaan, Ribeiro e Paolla (2017) apontaram que as tecnologias digitais trouxeram para o universo das crianças uma nova cor, uma nova forma de brincar e aprender. Cabe na palma da mão o conhecimento sobre cores, frutas, animais e cantigas que os pequenos demonstram muito interesse. A partir disso, as crianças usam as tecnologias, tablet $e$ smartphones para jogar, assistir vídeos, ouvir músicas, ver e tirar fotos, o que estimula os sentidos, ajuda no desenvolvimento mental e também no desenvolvimento da oralidade. Além disso, essas crianças usam alguns aplicativos de jogos.

\subsubsection{O uso da tecnologia desencadeia comportamentos não assertivos}

Outros entrevistados afirmaram que as crianças ficam distraídas, irritadas, desobedientes e nervosas, a ponto de destruir o celular, quando não consegue utilizá-lo; algumas permanecem em período integral jogando e nem saem de casa. 
"E aí quando dava pra ele e aí internet caía, ele ficava nervoso. Ele quebrou o meu celular [...], quebrou tudo a tela." (E5).

As crianças reproduzem o que assistiram no vídeo e ou na televisão, se comportando conforme os personagens.

"A única coisa é a modinha que pega, vê um vídeo, YouTuber fazendo tal coisa, aí quer fazer igual [...]quer copiar" (E21).

E deixam de realizar atividade que desenvolviam antes de adquirir a tecnologia, como ler livros e brincar; utilizam de xingamentos na comunicação verbal.

"Porque ela depois que ganhou o bendito do celular mudou totalmente. Ela lia 2/3 livros por semana [...] Muda [comportamento]. Tanto, tipo, em gestos, verbalmente, porque tem muito palavrão, essas coisas, muda bastante" (E15).

O cenário contemporâneo tem como marca a inserção das TDIC, desse modo percebe-se que as brincadeiras são outras e os brinquedos estão em outra plataforma: a digital. A boneca e o carrinho estão perdendo lugar para os aparatos tecnológicos; assim as crianças estão interagindo e socializando de forma diferente do passado (Canaan; Ribeiro \& Paolla, 2017).

Observou-se na fala dos entrevistados que a criança estava dependente do celular e o responsável está trabalhando essa dependência.

"Se deixar ela fica o dia inteiro. Ela viciou nesse celular. Essa madrugada ela acordou umas 5 horas [...] pedindo celular. Eu estou tentando tirar, mas está difícil" (E13).

Para Santos (2017), embora não haja consenso, a superexposição das crianças à tecnologia já aponta alguns problemas, e entre eles estão irritabilidade, isolamento, desinteresse pela interação com o outro. Para a Azevedo (2016), faz se necessário estabelecer limites de horários e mediar o uso com a presença dos pais para ajudar na compreensão das imagens. Equilibrar as horas de jogos online com atividades esportivas, brincadeiras, exercícios ao ar livre ou em contato direto com a natureza.

\subsection{O monitoramento no uso das tecnologias}

\subsubsection{Os pais monitoram o uso de tecnologias}

Os entrevistados disseram que estão sempre acompanhando, identificando o conteúdo acessado pelas crianças na televisão e no celular. Esse acompanhamento é realizado por 
meio da instalação dos desenhos e vídeos e da identificação do histórico do celular pelos pais; assim reconhecem os tipos de vídeos e jogos acionados e o assunto pesquisado. Um responsável bloqueia sites e canais e determina a plataforma e a categoria que as crianças podem acessar.

"A gente tem o controle. Tem alguns sites que deixamos bloqueados, também algumas consultas a gente não consegue entrar" (E19).

Eles se preocupam com o conteúdo assistido pelas crianças na televisão. Se tiver muitas cenas de lutas, violências, linguagem verbal inapropriada, os pais alteram a emissora.

"Se for desenho que minha menina põe sobre luta, essas coisas de palavrão, eu mando ela tirar" (E4).

E para as crianças entre 7 a 10 anos, os entrevistados pactuam que antes de assistir televisão e/ou acessar o celular, as crianças precisam realizar as tarefas da escola e domiciliares e/ou realizar as refeições.

"Isso [...], ela faz a tarefa dela de casa e arrumar as coisinhas dela, [...] e depois ela ver televisão." (E24).

Uma mãe refere que não permite a criança muito tempo no celular ou na televisão e, assim, se entretém com a criança, brincando, cozinhando.

"Ah eu invento outra coisa 'vamos sentar no chão, vamos brincar de boneca, a mãe vai brincar com você ou então vamos lá fazer um bolo, ajudar a mamãe." (E10).

Os entrevistados argumentaram sobre a importância do monitoramento do uso de tecnologia, pois há conteúdos que são impróprios para as crianças e elas mesmas acabam assistindo por inocência.

Canaan, Ribeiro e Paolla (2017) apontam que diante do exposto, defendem que as crianças tenham acesso às tecnologias e as mídias digitais com o acompanhamento de adultos. Recomendam que os pais observem o que os filhos estão assistindo e, se possível, bloqueiem alguns aplicativos ou sites inapropriados para elas; a mesma recomendação se aplica para a televisão, o smartphone e os demais aparatos tecnológicos.

Azevedo (2016) orienta monitorar os sites/ programas/ aplicativos/ filmes/ vídeos que crianças e adolescentes estão acessando/visitando/trocando mensagens, sobretudo em redes sociais. Manter os computadores e os dispositivos móveis em locais seguros, e ao alcance das responsabilidades dos pais (na sala) ou das escolas (durante o período de aulas). 


\subsubsection{Os responsáveis não monitoraram o uso das tecnologias}

Identificou-se que alguns responsáveis não costumam definir horários, não coloca limites, a criança pode assistir televisão em qualquer horário e os conteúdos que desejarem, considerando desnecessário o não monitoramento. Esses responsáveis, em geral, são tias ou avós.

"[...] eles não tem [horário para assistir]. Quando está alguém e a gente não está na sala, eles assistem. [o conteúdo que desejarem]. É livre" (E20).

Os entrevistados apontaram que os pais e ou responsáveis estão com dificuldade de acompanhar o uso e o conteúdo tecnológico acessado pelas crianças por falta de disponibilidade de horário e por confiarem que as crianças não vão acessar programas impróprios.

"Eu acredito que nem todos [fazem acompanhamento do uso da tecnologia]. Às vezes eu penso que nem é por mal, [pais] sempre queremos o melhor para os filhos, mas tem pai e mãe que, às vezes, não tem tanta disponibilidade no horário ou às vezes se distrai ou às vezes, até eu mesmo, distraída com uma atividade doméstica, alguma coisa." (E21).

Dessa forma, as crianças de três a dez anos permanecem um longo período do dia acessando celular ou assistindo televisão, trancados no quarto e os bebês de quatro ou seis meses já estão observando vídeo no celular.

Segundo Azevedo (2016) deve-se limitar o tempo de exposição às mídias ao máximo de 1 hora por dia, para crianças entre dois a cinco anos de idade. Crianças até 10 anos não devem fazer uso de televisão ou computador em seus quartos. Adolescentes não devem permanecer isolados em seus quartos ou ultrapassar suas horas saudáveis de sono às noites (8-9 horas/noite/fases de crescimento e desenvolvimento cerebral e mental). A atividade física diária por uma hora deve ser estimulada.

Mesmo com tantas recomendações, muitos pais parecem não se preocupar com o assunto. Sob a justificativa de que hoje é importante saber trabalhar com as novas tecnologias desde cedo ou simplesmente para evitar aborrecimentos, os pais acabam deixando as crianças livres para usar os equipamentos da forma como quiserem, o que pode causar problemas não só aos pequenos, mas para toda a família (Santos, 2017).

Para Souza e Oliveira (2016) crianças e adolescentes não tem plena capacidade de perceber os potenciais riscos e prejuízos que estão expostas por ainda estarem em 
desenvolvimento físico e psicológico e por isso são alvos fáceis de crimes pela internet como ciberbullying, pornografia, pedofilia, aliciamento, assédio, corrupção de menores, venda de drogas e medicamentos, entre outros. Os autores compreendem que: é dever coletivo entre especialistas da academia, da informática, organizações e governo construir, divulgar e assegurar estratégias de educação direcionadas à navegação segura internet para responsáveis, educadores, crianças e adolescentes; é importante o apoio e cooperação dos provedores de serviços de internet em investigação de crimes pela internet; é necessário o reconhecimento dos deveres de todos, família, sociedade civil e estado, sobre o auxílio e proteção integral das crianças e adolescentes.

\subsection{O desenvolvimento da criança e o uso da tecnologia}

\subsubsection{Potencializando o desenvolvimento da criança devido ao uso da tecnologia}

Os relatos dos entrevistados em relação aos benefícios do uso das tecnologias, a maioria afirma que as crianças se tornam mais espertas no sentido de construir novos conhecimentos, como também, reproduzem a obediência que observaram nos vídeos. $\mathrm{E}$, mais, a tecnologia contribui para elaboração dos trabalhos da escola.

"[...] tem desenho que fala de cores, de números, é, ensinam os alfabetos, isso aí eu sei que a tecnologia ajuda muito" (E4).

Em relação ao uso da tecnologia na escola, alguns apontaram que é bom, pois ensinam as crianças a usarem de maneira correta o computador, a pesquisarem e se desenvolverem.

"É bom na escola, aula. Tipo, na aula de informática para alunos fazerem pesquisas para trabalho essas coisas assim." (E1).

A televisão e o computador podem ser aliados do processo pedagógico, se usados de forma complementar, promovendo interação (Pereira \& Arrais, 2015).

O interesse das crianças pelas redes, internet e mídias digitais parece não ser só de "interagir com a máquina" e sim com outras crianças através da tecnologia. Desta forma, o que está em jogo são os vínculos construídos e não a interatividade em si, pois crianças de diferentes contextos socioculturais, nas mais adversas condições estão aprendendo a brincar, a ganhar, a perder, a socializar e a se organizar e redes através da cultura digital (Fantin, 2015). 


\subsubsection{Prejudicando o desenvolvimento da criança devido ao uso da tecnologia}

E quanto aos malefícios, aparece o comprometimento da relação com pais e responsáveis, a limitação da criatividade, a ineficácia do desempenho escolar e a alteração de comportamento como, incentivo a realizar atitudes não éticas, dificuldade para viver o mundo real e aceitar as contradições, podendo adoecê-las.

“Ela fica muito estressada [...] não saber ouvir um não. Então [...] não é o mundo real que ela vive [...] é um mundo muito fantasia [...] Acho que as crianças hoje vêm entendendo dessa maneira, nunca ouvindo não, por isso que vem tendo essa crise de depressão [...]" (E19).

Os objetos tecnológicos podem levar a um comodismo, referente ao pensar, criar, pois as tecnologias se desenvolvem com finalidade de facilitar as ações cotidianas (Pereira \& Arrais, 2015).

Canaan, Ribeiro e Paolla, (2017) referiram que alguns estudiosos que atuam no campo da educação afirmam a existência de limites que devem ser impostos para o bom uso das mídias digitais pelas crianças. Observa-se que os infantes vivem em dois mundos: o real e o digital/virtual, que por um lado se revela interessante, oferecendo aventuras e oportunidades, e por outro, perigo e riscos à saúde.

Cruz (2018) refere-se a importante de problemas relacionados ao desenvolvimento das crianças e adolescentes, identificando a crescente dificuldade de se manifestarem quando estão em grupo, em construírem uma identidade coesa, harmoniosa e integradora e que essa dificuldade advêm de matrizes familiares inconsistentes, de sociedades exigentes, que valorizam o individual em detrimento do coletivo, enfatizando resultados acadêmicos e o sucesso a qualquer custo.

Alguns entrevistados criticaram os pais que comentaram que não permitiriam o uso do celular pela criança, mas que o oferecerem no intuito de acalmá-las e, posteriormente, a aquisição é efetivada.

“Então pai e mãe que fala: 'aí meu filho não vai assistir celular, vai ficar só brincando' é tudo mentira! Minha tia falava a mesma coisa e hoje ela faz questão, estava até querendo deixar o celular só com criança, que ele derrubar e destrói [outros objetos]." (E18).

Outros afirmaram que preferem o método tradicional, onde as escolas não usam tablet durante as aulas.

“Não, tem que ser tradicional mesmo. Se não é demais, já basta em casa, ficar na escola também.” (E6). 
O contato muito cedo e contínuo influência no comportamento social, levando a criança a ter dificuldade de se relacionar em ambientes sociais (Pereira \& Arrais, 2015).

Souza (2018) ao analisar o impacto da tecnologia em crianças e adolescentes identifica que estes, ao se relacionarem com um tablet não precisam recrear, porque a resposta é ofertada e eles simplesmente respondem o que é solicitado; a função do imaginário é anulada porque esta pertenceu ao criador do jogo. Refere que o brincar, o fazer de conta, exige da criança a criatividade, criar história, enredo, personagens, imaginar-se naqueles papéis, lidar com conflitos, com a partilha, com renúncias, transferências e sentimentos. Identifica que tudo isso fica prejudicado com o uso intenso da tecnologia/internet.

As orientações da literatura são claras nos que se refere ao uso não abusivo ou controlado das tecnologias pelas crianças, as realidades são divergentes quando se fala da postura dos pais ou responsáveis nesse controle e isso pode colocar em risco o desenvolvimento biológico, psicológico e social desses inocentes.

De acordo com a Política Nacional de Atenção Integral a saúde da Criança, é fundamental estimular a integralidade do desenvolvimento cerebral-mental-cognitivo-psicossocial dos primeiros anos de vida, com atividades familiares, nas escolas e na comunidade; também traz a importância de acompanhar esse desenvolvimento em todos os níveis de atenção à saúde (promoção, proteção, atendimento, detecção precoce e reabilitação de alterações) que podem repercutir na vida futura da criança.

Considera que para a construção da autonomia da criança, a família e/ou responsáveis precisam de cuidados até que a criança adquira o senso de identidade (BRASIL, 2018). Nesse sentido, é importante que os profissionais da saúde e da educação estejam preparados para a identificação de problemas relacionados ao uso das tecnologias pelas crianças e que as ações para minimizar esses visem a integralidade do cuidado.

\section{CONSIDERAÇÕES FINAIS}

O presente estudo alcançou o objetivo proposto de analisar o uso de tecnologias e seu impacto no desenvolvimento das crianças. Mostrou que as tecnologias que as crianças mais acessam são a televisão e o celular. 
Quanto ao monitoramento das tecnologias, identifica-se que somente os pais entrevistados acompanham o seu uso, no entanto, eles não observam como as crianças se conectam as mídias.

Conclui-se que na sociedade contemporânea não há como negar o acesso a tecnologias pelas crianças, porém elas precisam ser monitoradas pelos pais e ou responsáveis a fim de que as mídias cessadas possam contribuir para potencializar o desenvolvimento da criança.

Considera-se a importância das ações políticas nesse contexto, tanto no setor da saúde como no da educação, buscando a integralidade do cuidado.

A pesquisa qualitativa possibilitou imergir no universo das crianças concernente ao uso de tecnologias, permitindo identificar potências e desafios quanto a esse acesso.

Embora a investigação se restringiu a uma população específica, traz possibilidades aos profissionais, pais e educadores de reflexão e, além de limitarem sua utilização, pensarem novas alternativas de diversão, como por exemplo, o resgate de brincadeiras coletivas, vividas pelos adultos nessa fase.

\section{REFERÊNCIAS}

Azevedo, A. E. I. et al. (out/2016). Manual de Orientação: departamento de adolescência. Saúde de crianças e adolescentes na era digital (№. 1, pp. 1-11). Sociedade Brasileira de Pediatria, Rio de Janeiro. Disponível em: https://www.sbp.com.br/fileadmin/user_upload/2016/11/ 19166d-MOrient-Saude-Crian-e-Adolesc.pdf. Acesso em: 5 set. 2019.

Brasil, Ministério da Saúde. (2018). Política Nacional de atenção integral à saúde da criança: orientações para implementação. Brasília. Disponível em: http://www.saude.pr.gov.br/arquivos/File/Politica_Nacional_de_Atencao_Integral_a_Saude_da_Crianca_P NAISC.pdf. Acesso em: 01 mar. 2020.

Canaan, M.; Ribeiro, L.; Paolla, Y. (2017). Tecnologias digitais e influências no desenvolvimento das crianças. (v. 1, № 8). Universidade EaD e Software Livre. Disponível em: http://www.periodicos.letras.ufmg.br/index.php/ueadsl/article/view/12240/ 10437. Acesso em: 5 set. 2019.

Gomes, R. Análise e interpretação de dados de pesquisa qualitativa. In: MINAYO, M. C. S. (Org.). (2016). Pesquisa social: teoria, método e criatividade. (Cap. 4, pp. 75-77). Petrópolis: Vozes.

Minayo, M. C. S. O desafio da pesquisa social. In: MINAYO, M. C. S. (Org.). (2016). Pesquisa social: teoria, método e criatividade. (Cap. 1, pp .20-21) Petrópolis: Vozes.

Minayo, M. C. S. Trabalho de campo: contexto de observação, interação e descoberta. In: MINAYO, M. C. S. (Org.). (2016). Pesquisa social: teoria, método e criatividade (Cap. 3, pp. 58-59). Petrópolis: Vozes. 
Moura, J. T. T. et al. (2012) A influência do desenho animado no processo sociocognitivo da criança. In: FÓRUM INTERNACIONAL DE PEDAGOGICA, 4aㅡ ed. Paraíba. Anais eletrônicos[...]. Paraíba: Realize. Disponível em: http://editorarealize.com.br/revistas/fiped/trabalhos/0913b76c1e 17edd8a8eb9f35c9553d88_1811.pdf. Acesso em: 11 jun. 2018.

Santos, J. (2017). Uso de tecnologia por crianças: benefício ou perda da infância? Paraná: Sempre Família. Disponível em: https://www.semprefamilia.com.br/uso-de-tecnologia-por-criancas-beneficio-ouperda-dainfancia/. Acesso em: 5 set. 2019.

Wallbach, E. M. R. (2010). A tv e a criança. Curitiba: Grupo Psicanalítico de Curitiba. Disponível em: http://www.gpc.org.br/tv-e-crianca-edna-maria-romano-wallbach-2010/. Acesso em: 12 jun. 2018.

Pereira, B. S.; Arrais, T. S. (jun/2015). A influência das tecnologias na infância: vantagens e desvantagens. Universidade do Estado do Rio de Janeiro, Rio de Janeiro. Disponível em: http://www.pucrs.br/ciencias/viali/doutorado/ptic/aulas/aula_2/EV047.pdf. Acesso em: 16 abr. 2020.

Fantin, M. (2015). Crianças e games na escola: entre paisagens e práticas. Revista Latinoamericana de Ciências Sociales, Niñezy Juventud, (V. 13, №1, pp. 195-208). Disponível em: scielo.org.co/pdf/rlcs/v13n1/v13n1a12.pdf . Acesso em: 16 abr. 2020.

Cruz, P. M. F. A. (2018). Impacto da tecnologia em grupanálise com crianças e adolescentes. (v. 15, № 2). Vinculo- Revista do NESME. Disponível em: http://pepsic.bvsalud.org/pdf/vinculo/v15n2/ v15n2a06.pdf. Acesso em: 16 abr. 2020.

Souza, D. A.; Oliveira, J. A. M. (out-nov/2016). Uso de tecnologias digitais por crianças e adolescentes: potenciais ameaças em seus inter-relacionamentos. XIII SEGeT- Simpósio de Excelência em Gestão e Tecnologia. Resende- Rio de Janeiro. Disponível em: https://www.aedb.br/seget/arquivos/artigos16/952473.pdf. Acesso em: 16 abr. 2020. 